\title{
ADMINISTRATIVE DECISIONMAKING IN NUCLEAR FACILITIES LICENSING
}

\author{
DaVId F. GaVERS $\dagger$
}

In discharging its most important regulatory function-the licensing of nuclear facilities (mainly reactors)-the United States Atomic Energy Commission has encountered two difficult and serious problems. One is how to create and maintain public confidence in the objectivity of its decisions as to the safety of the facilities it licenses. The other is how to assure, as nearly as possible, the validity of those decisions-decisions which often involve scientific and engineering judgments of an exceedingly difficult and recondite character. Solutions to both of these problems must take into account the fact that, in addition to its regulatory duties, the AEC is charged with administering a vast military procurement and development program and with promoting and developing the peaceful uses of atomic energy, including, of course, the promotion and development of atomic power.

The Commission has sought to warrant the objectivity of its decisions by judicializing the licensing process, that is, by carefully observing procedural formalities and isolating the hearing examiner and even the Commission itself from its own technical staff. ${ }^{1}$ And it has sought to assure the technical validity of safety decisions reached at the prehearing stage of the licensing process by supplementing the views of its technical staff with those of the statutory Advisory Committee on Reactor Safeguards (ACRS), a fifteen-man, part-time body of scientists and engineers which advises the Commission on the basis of very informal inquiries.

The success of these measures is at best questionable. Judicialization of the licensing process can scarcely reassure a worried community

$\dagger$ Fessenden Professor of Law, Harvard Law School. B.S. 1923, University of Pennsylvania; LL.B. 1926, Harvard University. The views expressed in this article are the personal views of the author and not necessarily those of the staff of the Joint Committee on Atomic Energy, with which he has been associated as consultant in its study of the AEC's regulatory process.

1 The procedure governing AEC licensing of facilities is outlined, with illustrative case histories, in 1 STAFF of JoINT COMM. ON ATOMIC ENERGY, 87TH CoNG., 1ST Sess., Improving the AEC Regulatory Process 19-24, 27-40 (Jt. Comm. Print 1961) [hereinafter cited as JCAE STAFF STUDY]. For a more complete description, with detailed case chronologies, see AEC, The Regulatory Program of the Atomic Energy Conmission [hereinafter cited as $A E C^{\prime}$ 's Regulatory Program], in $2 \mathrm{JCAE}$ STAFF STUDy 87-393. For an excellent treatment which is historical and evaluative as well as descriptive, see Berman \& Hydeman, The Atomic Energy Commission and Regulating Nuclear Facilities 64-154 (1961) [hereinafter cited as Beraian \& HYDEMAN]. For the pertinent regulations, see 10 C.F.R. $\$ \$ 2.1-.814$ (1959) (rules of practice), $\$ \$ 50.1-.110$ (1959) (licensing of production and utilization facilities). 
that the Commission, which in its promotional and developmental functions has been encouraging and even agreeing to subsidize ${ }^{2}$ an applicant before the licensing process has begun, will achieve disinterested detachment when the application for a construction permit reaches it some months or years later, bearing the approval of both its own staff and the ACRS. Although the prehearing process for evaluating safety is good, if currently cumbersome, there is no effective review of the merits of the safety decisions it produces in the absence of intervention by a third party, and intervention is so costly and time-consuming that it can seldom be expected to take place. Moreover, even if intervention does occur, the present procedure is likely to impair the effectiveness of the review.

The present procedures have another complaint to answer: they are so time-consuming and costly to the applicant that they are likely to deter entry into the still economically unattractive atomic power industry. Moreover, although the Commission has made extensive delegations of its regulatory functions, the Commissioners report that they have been devoting from one-sixth to one-third of their time to regulatory matters ${ }^{3}$ and yet "concede that in the past" the Commission "was slow in developing rules and regulations for the licensing of utilization facilities and materials." 4

These inadequacies have led to extensive study of the AEC's regulatory structure and procedures. The Commission began to encounter difficulties in passing on the safety of nuclear facilities within two years of the adoption of the Atomic Energy Act of $1954,{ }^{5}$ the statute which first authorized nongovernmental reactors. In 1956 the problem of public confidence came to the fore with the United Auto Workers' intervention to contest the grant of a conditional construction permit to the Power Reactor Development Company to build a Fermi fast-breeder reactor on the shores of Lake Erie about midway between Detroit and Toledo. Soon thereafter, a study of the AEC regulatory process was begun by the staff of the Joint Committee on Atomic

2 The Atomic Energy Act of 1954 forbids direct subsidization, $\$ 169$, 68 Stat. 952, 42 U.S.C. \$2209 (1958), but permits research assistance, §31, 68 Stat. 927, as amended, 42 U.S.C. $\$ 2051$ (1958), and the waiver of charges for the use of nuclear fuel, $\$ 53(\mathrm{c}), 68$ Stat. 930 , as amended, 42 U.S.C. $\$ 2071$ (c) (1958), both running into many millions of dollars. This system was termed "no subsidy" subsidization" in Cavers, Atomic Power: The Quest for a Program, 27 Geo. Wase. I. REv. 427, 457 (1959).

3 Letter From AEC Commissioner J. S. Graham to James T. Ramey, Executive Director, Joint Committee on Atomic Energy, Oct. 28, 1960, in 2 JCAE STAFF STUDY 574.

4 Hearings on Radiation Safety and Regulation Before the Joint Committee on Atonic Energy, 87th Cong., 1st Sess. 299 (1961) [hereinafter cited as Hearings on Radiation Safety and Regulation].

568 Stat. 919 (1954), as amended, 42 U.S.C. $\$ \$ 2011-281$ (1958), as amended, 42 U.S.C. $\$ \$ 2016-203$ (Supp. II, 1961). 
Energy, and, in response to its recommendations, ${ }^{6}$ amendments to the Atomic Energy Act were enacted in 1957, making public hearings mandatory in the licensing of power and test reactors, ${ }^{7}$ giving statutory status to the ACRS, ${ }^{8}$ and requiring it to make public reports concerning the safety of proposed reactors. ${ }^{9}$

\section{Three Recent Studies}

Since the 1957 Joint Committee staff report, experience in the licensing of nuclear facilities has grown much greater and, of course, reflects changes made in response to the 1957 amendments. Last year the timeliness of a new look at the system's operation was remarked both by Senator Clinton Anderson, then Chairman of the Joint Committee on Atomic Energy, and by the then Chairman of the AEC, John A. McCone. ${ }^{10}$ Two government-sponsored studies ensued: a self-study by the $A E C^{11}$ and a new study by the Joint Committee staff, ${ }^{12}$ in which the author participated as a consultant, together with William Mitchell, former General Counsel of the AEC. About the same time the codirectors of the Atomic Energy Project of the University of Michigan Law School, William $H$. Berman and Lee M. Hydeman, instituted a study of the same subject. ${ }^{13}$ All three studies

- Staff of Joint Comm. on Atomic Energy, 85Te Cong., 1St Sess., A Study of AEC Procedures and ORganization in the Licensing of REACtor Facilities 25, 33, 34 (Jt. Comm. Print 1957).

${ }^{7}$ Atomic Energy Act of 1954, $\$ 189$ (a), as amended, 71 Stat. 579 (1957), 42 U.S.C. $\$ 2239$ (a) (1958). A hearing after thirty days' notice published in the Federal Register is required only for: (1) facilities for which $\$ 103,68$ Stat. 936 (1954), 42 U.S.C. \$2133 (1958), requires "commercial licenses" (none as yet has been sought), (2) facilities "involved in the conduct of research and development activities leading to the demonstration of the practical value of such facilities for industrial or commercial purposes," \$104(b), 68 Stat. 937 (1954), 42 U.S.C. \$2134(b) (1958), which is the legal basis for the nonmilitary power reactors licensed to date; and (3) test reactors-used for testing materials under radiation-licensed under $\$ 104$ (c), 68 Stat. 937, 42 U.S.C. $\$ 2134$ (c) (1958). Licensing of research reactors and "critical assemblies" (devices maintaining a fission chain reaction at virtually zero power level) has been delegated to the AEC Division of Licensing and Regulation. See AEC MANUAL \$ 0103-083 (Feb. 1960). Reference to the ACRS is discretionary in licensing proceedings as to which no hearing is required. Atomic Energy Act of 1954, \& 182(b), added by 71 Stat. 579 (1957), 42 U.S.C. \$2232(b) (1958). In such proceedings, licenses take effect thirty days after notice published in the Federal Register unless intervention or a public hearing is requested.

8 Atomic Energy Act of 1954, $\$ 29$, added by 71 Stat. 579 (1957), 42 U.S.C. $\S 2039$ (1958).

9 Atomic Energy Act of 1954, § 182(b), added by 71 Stat. 579 (1957), 42 U.S.C. §2232(b) (1958).

10 This background is reported in 1 JCAE STAFF Study 7-9. See also Holifield, Foreword to id. at v.

11 AEC's Regulatory Program, in 2 JCAE STAFF Study 87-393; AEC, Report on the Regulatory Program of the Atomic Energy Commission [hereinafter cited as Report on the Regulatory Program], in 2 JCAE STAFF STUDy 395-423.

121 JCAE STAFF Study.

13 See note 1 supra. 
were completed early in 1961 and formed the subject of hearings before the Joint Committee in mid-June 1961.

Although these studies also considered the AEC's extensive activities in the licensing of nuclear materials and of nuclear waste disposal, their main concern was with the licensing of nuclear facilities. This article will similarly be directed to facilities licensing and will discuss the two problems noted at its start. It will draw extensively on the three studies and on the Joint Committee hearings. The respective positions of the studies on basic issues of licensing may be summarized as follows:

The AEC study recommended continuation of the Commission's present regulatory structure and procedures, with internal changes to facilitate action on regulatory matters by the Commission, and modification of the 1957 amendments to make a public hearing mandatory only at the construction permit stage, absent intervention and the existence of "substantial novel safety questions." 14 The study intimates that possibly, in the absence of such questions, reference to the ACRS might also be dispensed with. ${ }^{15}$

The Joint Committee staff study recommended that a threemember "Atomic Safety and Licensing Board" be created within the framework of the AEC, to be appointed by the President and authorized to make final dispositions--subject only to judicial reviewin all licensing proceedings under the Atomic Energy Act and in authorization proceedings involving Government-owned nonmilitary reactors. ${ }^{16}$ Two of the members would be "technically qualified." Rulemaking power would be retained by the Commission, though the Board would be consulted. The study's proposals for relaxing the requirements for public hearings and reference to the ACRS were similar to those advanced in the AEC study. ${ }^{17}$

The Berman-Hydeman study proposed that a similar threemember board be created in a separate agency to which the AEC's

14 Report on the Regulatory Program, in 2 JCAE Staff Study 410.

$15 I d$. at 406.

16 Presumably this board would delegate research reactor licensing to the staff. See also note 7 sipra. An important problem not yet wholly solved is the review to be given three types of power and test reactors not subject to the licensing process: reactors built by the AEC for public or cooperative electric systems, to which the $\mathrm{AEC}$ retains title; reactors built by the $\mathrm{AEC}$ for its own use on its own sites; and reactors built by or for other federal departments or agencies. For reactors in the first category, the prime contractor must get from the AEC a "construction authorization" and an "operating authorization" by following procedures paralleling those for reactors not owned by the AEC, including reference to the Advisory Committee on Reactor Safety (ACRS) and public hearings. See Procedures for Review of Certain Nuclear Reactors Exempted from Licensing Requirements, 26 Fed. Reg. 4321 (1961). These procedures could be extended (with appropriate modifications) to nonmilitary reactors in the second two categories, as is being done for the U.S. Maritime Administration's N. S. Savannah.

17 For a summary of the staff's plan, see 1 JCAE Stafr Study 69-75. 
present regulatory powers and staff would be transferred. The study also recommended replacing the Commission with an Atomic Energy Administrator, who would participate in rulemaking by the Board. The sharing of space and certain services were suggested to preserve contact between the two agency staffs. The study recommended that the requirement of a public hearing be retained in uncontested cases, but that it be reexamined in two or three years and restricted in the interim to a single hearing at the construction permit stage. ${ }^{18}$

\section{An Illustrative Case: The Peach Bottom Reactor}

The problems that have led to the foregoing proposals can be made concrete by reference to a pending proceeding-the Philadelphia Electric Company's application to construct an advanced high-temperature, helium-cooled, graphite-moderated reactor of 40,000 kilowatts, at Peach Bottom, York County, Pennsylvania. ${ }^{19}$

The Peach Bottom reactor proposal was made in response to an invitation by the AEC in September 1958 to the electric industry to construct, with AEC aid for research and fuel costs, a gas-cooled reactor. The act authorizing the construction fixed a deadline of sixty days for the receipt of private bids, and, if no satisfactory bids were received or negotiations thereafter failed, the AEC itself was to build the reactor and use the electric energy it generated. ${ }^{20}$ Just before the sixty-day deadline, the Peach Bottom proposal was filed by Philadelphia Electric together with High Temperature Reactor Development Associates, Inc., a hastily assembled nonprofit institution comprising fifty-two "investor-owned" electric utility companies. ${ }^{21}$ The proposal was not wholly responsive to the invitation, but, rather than lose the chance for a new partnership with the electric industry, the AEC persuaded the Joint Committee on Atomic Energy to sponsor legislation clearing the way for the Peach Bottom reactor. This was needed, for, while the bidders were prepared to invest an aggregate of $\$ 24,500,000$, the United States was requested to agree to supply $\$ 15,000,000$ for research and $\$ 2,000,000$ by the waiver for five years of the four per cent use charge on nuclear fuel supplied for the reactor

18 For the authors' plan, see Berman \& Hydeman 319-31. The Board would also serve as "a focal point" for the various radiation control responsibilities of the federal government, superseding the Federal Radiation Council, an interagency body given statutory recognition in 1959. Atomic Energy Act of 1954, $\$ 274(\mathrm{~h})$, added by given statutory recognition in 13 Stat. 690 (1959), 42 U.S.C. $\$ 2021$ (h) (Supp. II, 1961).

19 In the Matter of Philadelphia Elec. Co., No. 50-171, AEC, July 25, 1960.

20 Act of Aug. 4, 1958, §110, 72 Stat. 494.

21 For a brief account of its genesis, see Hearings on AEC Authorization Legislation Fiscal Year 1960 Before the Subcommittee on Legislation of the Joint Committee on Atomic Energy, 86th Cong., 1st Sess. 70-71 (1959). 
by the United States, the only lawful owner of the kind of fuel needed. Having obtained the necessary authorization ${ }^{22}$ and appropriation, the AEC then negotiated contracts with Philadelphia Electric and its investment partner, and with General Dynamics Corporation, which was to do the research and development work on the project.

Obviously this sequence of events required repeated and careful attention by the Commission and protracted study and negotiation by its staff. Not only was the possibility of a significant advance in power reactor design at stake, but, in creating High Temperature Reactor Development Associates, Inc., "private power" had rallied its forces to fend off the menace of another government owned and operated electric power plant, an effort to which both the Administration and the Commission were warmly sympathetic. Clearly, then, in its capacity as promoter and developer, the Commission was deeply committed to Peach Bottom.

Since the signing of the contract in August $1959,{ }^{23}$ work on design has been going forward, and various subcontracts have been let. But to obtain the permit required by section 185 of the Atomic Energy Act of $1954^{24}$ before commencing construction, Philadelphia Electric has had to approach the Commission once more, this time not as the AEC's invitee or as its associate in a common venture, but as an applicant seeking a decision that "a reactor of the general type proposed can be constructed and operated at the Peach Bottom site without undue risk to the health and safety of the public." ${ }^{25}$ At this stage applicants must deal with the AEC's Division of Licensing and Regulation, not with the Division of Reactor Development.

Well before the Peach Bottom reactor design was far enough along to sustain an application for a construction permit, Philadelphia Electric sought preliminary indications from the ACRS as to the suitability of its site. Although several cities are within a twenty-five mile radius of the reactor, ${ }^{26}$ the ACRS concluded that the "site provides a generally acceptable degree of isolation when considered in

22 Act of June $23,1959, \S 110(\mathrm{f}), 73$ Stat. 85 . Since a 1957 amendment to $\$ 261$ of the act, 71 Stat. 274 (1957), 42 U.S.C. $\$ 2017$ (1958), cooperative power demonstration programs have required authorizations for appropriations.

23 AEC Release No. B-145, Aug. 27, 1959.

2468 Stat. 954, 42 U.S.C. \$2235 (1958).

25 This is the key finding to be made when a provisional construction permit is sought. See 10 C.F.R. $\$ 50.35$ (1959).

26 For the site data, see Hearings on AEC Authorization Legislation Fiscal Year 1960 , supra note 21 , at 79-80. The proposed site is located in a relatively thinly populated area on the Susquehanna River (4,000 people within a radius of 5 miles), within 19 miles of Lancaster, Pennsylvania, 22 miles of York, Pennsylvania, and about 25 miles from Baltimore, Maryland, which, in order to supplement its present supply, proposes to draw water from the Susquehanna River above the big Conowingo Dam, the intake being about nine miles downstream from the site. 
relation to the proposed high integrity containment." ${ }^{27}$ On further review, after the Company had applied for a construction permit, the ACRS, though recognizing that the "initial results" of the "extensive research and development program related to this reactor . . . appear to be favorable," identified a series of unresolved questions "in areas which could require major changes in the present design concepts and could conceivably change our early optimism." It declined, therefore, "to go beyond its original conclusion" as to the suitability of the site. ${ }^{28}$

Rumblings of concern were heard in the vicinage. Shortly after the Court of Appeals for the District of Columbia ruled against the use of a conditional construction permit in the Power Reactor Dev. Co. case $^{29}$ - a decision later reversed by the Supreme Court ${ }^{30}$-thenCongressman James M. Quigley wrote the AEC asserting his agreement with the Court of Appeals decision and declaring that "the time to resolve any threat to public safety . . . is now and not after millions of dollars of the taxpayers' money have been spent. . . ." 31 And Dr. C. L. Wilbar, Pennsylvania Secretary of Health, wrote the company for more data on certain design problems, including several not raised in the ACRS or AEC statements, and declared that his department would have to intervene if these were not forthcoming. ${ }^{32}$

In April 1961 the AEC's Division of Licensing and Regulation ruled by letter that the information submitted by the company did not warrant issuance of a construction permit and noted lines along which further research and development data were needed, much the same lines as the ACRS had already indicated. ${ }^{33}$

After the new data had been furnished, representatives of the applicant, the contractor, and the AEC staff met with a subcommittee of the ACRS on October 3,1961, and with the full committee on October 27. In a letter dated November 1, the ACRS advised Chairman Seaborg of the AEC that "since the continuing research program gives reasonable assurance that all health and safety problems can be satisfactorily resolved, the ACRS believes ..." (and here follows the key finding noted above) that there is "reasonable assurance that it [the

27 Report of Advisory Committee on Reactor Safeguards, United States Atomic Energy Commission, in 2 CCH Atom. ENERGY L. ReP. II 10396 (March 14, 1960).

28 See AEC Release No. C-259, Dec. 23, 1960.

${ }^{29}$ International Union of Elec. Workers v. United States, 280 F.2d 645 (D.C. Cir. 1960).

30 Power Reactor Dev. Co. v. International Union of Elec. Workers, 367 U.S. 396 (1961).

316 Atomic Ind. Rep., News and Analysis 271 (1960).

32 Id. at 336.

33 Letter From Robert Lowenstein, Acting Director of the Division of Licensing and Regulation, to the Philadelphia Electric Company, April 15, 1961. 
reactor] can be operated without undue risk to the health and safety of the public." ${ }^{34}$

The ACRS letter is longer than is customary; it devotes a page to listing various design improvements adding to safety and briefly identifies the two points as to which the research and development program gives the "reasonable assurance" it reports. With respect to one of these, it makes the comforting notation that "should later results indicate that a reliable system can not be obtained by the present approach, alternate methods appear to be available" to achieve the desired purpose. ${ }^{35}$

No doubt the AEC staff shares the ACRS's views. Two weeks after receiving them, the Division of Licensing and Regulation published notice that a public hearing would be held on December 18, 1961, at AEC headquarters in Germantown, Maryland. ${ }^{38}$ If the company had failed to get the staff approval that can be inferred from this notice, its chances of obtaining a favorable decision by pressing its case before the hearing examiner or on appeal to the Commission would have been slight. But now that this approval has been won, certain events can be predicted with some assurance.

The staff of the Division of Licensing and Regulation will at once be "separated for the purposes of the case from both the Commission and the hearing examiner." At the hearing the applicant and the staff will doubtless offer testimony in support of the application. Conceivably Representative Quigley's successor will seek to intervene and be permitted to do so, but the Supreme Court's decision in the Power Reactor Dev. Co. case has left him with no legal basis for

34 See AEC Release No. D-303, Nov. 7, 1961.

35 The ACRS's reference to the alternative bears on a problem suggested by the Power Reactor Dev. Co. case, in which the AEC's finding of "reasonable assurance" was sustained although research essential to a final determination of the safety of the general type of reactor there involved remained to be completed. The Commission's statement that its finding was "for the purposes of the provisional construction permit" was said by the Supreme Court to be "merely declaratory of the nature of the proceeding" so that it "in no way denigrated the finding as to safety of operation." Power Reactor Dev. Co. v. International Union of Elec. Workers, 367 U.S. 396, 410 (1961). Yet the Commission's phrase highlights the fact that neither the statute nor the regulations restrain the optimism with which the AEC may view the prospects of incomplete yet essential research or development work. If the purpose of the act's two-stage licensing process is to be preserved, it may sometimes be necessary to require a finding as to the existence of a safe and practicable alternative way to solve a problem which the applicant is seeking to solve by a method the safety of which is still being studied. See Berman \& Hydeman, Licensing Reactor Facilities, 2 AtoM. ENERGY L.J. 105, 133 (1960), in which the authors say that a finding of reasonable assurance that the research questions are likely to be resolved favorably should be sufficient.

36 See 26 Fed. Reg. 10736 (1961). Ten days before the hearing, the AEC sponsored an informal public meeting at Delta, $\mathrm{Pa}$., to discuss its regulatory system and safety questions concerning the Peach Bottom plant. The meeting, attended by about 160 persons, mostly citizens of the area, is said to be viewed by the AEC as a "success" from "the public information point of view." Forum Memo Jan. 1962, p. 23. 
objecting to a provisional permit, and what can he say to alter the findings that the staff and applicant are ready to write for the examiner? And what can the examiner do other than to accept the proffered findings-save in the unlikely event that some sloppy staff work should leave a point uncovered? Even if the State Health Department intervenes (an improbable contingency when both the AEC staff and the ACRS are satisfied), it too is unlikely to undermine the applicant's case; at best the Department may get some additional conditions written into the permit, to be satisfied before an operating license is granted. Unless, therefore, some anxious and militant citizens' group can afford to enlist a good lawyer and can find a group of competent nuclear physicists who are able and willing to take issue with the staff and the ACRS, the company will have cleared the first hurdle on the road to an operating license. Absent exceptions to the examiner's order, the Commission will look at the record of the public hearing, aided by a summary prepared by counsel assigned to the Commission by the General Counsel for aid in licensing cases. ${ }^{37}$ It will almost certainly approve the order; the Commission simply cannot dig back into the primary data and the applicant's discussions with the staff and the ACRS so as to get to the bottom of the problems they have resolved in the applicant's favor.

Two or three years and many meetings later, the applicant may have completed constructing the reactor and be prepared, by satisfying the conditions prescribed in the construction permit, to show that it is entitled to an operating license. Again this can be done only if it can convince the staff and the ACRS that the data derived from further research and development or design modifications have provided the needed safety assurance. Probably the new picture will not be free from ambiguity; doubts will have to be resolved; but there seems little chance that the Commission which had provided large-scale aid and had allowed the reactor to be completely constructed would suddenly override the judgment of its staff and the ACRS and convert a $\$ 50,000,000$ ready-to-run reactor into an historical monument. If either the staff or the ACRS did not believe that the operating license should issue, maybe the company would contest that position; possibly, after the protracted ceremony of a hearing before an examiner and the filing of his intermediate opinion, the company could persuade the Commission to issue the operating license it sought, perhaps on some provisional basis. ${ }^{38}$ Having made the investment, the company would

37 Hearings on Radiation Safety and Regulation 312-14 (testimony of Commissioner Olson).

38 The AEC regulations have been recently amended to authorize "provisional operating licenses." See 10 C.F.R. § 50.57 (Supp. 1961). 
have little to lose by appeal, and the technical issues might well be of a sort that could be resolved reasonably in either direction.

The Peach Bottom case is somewhat more troublesome than the usual reactor licensing proceeding, in that the Commission's involvement in preapplication dealings with the applicant has been greater than is typical, and the reactor itself poses more than the usual number of safety questions. However, the adequacy of a regulatory process is not to be gauged simply by its aptness for the run-of-the-mill case, and the complications of Peach Bottom are by no means unique.

\section{The Problem of the Commission's Dual Responsibilities}

The AEC's own study views the conflict caused by the Commission's dual responsibility as adequately met by the separation of the staff and the basing of Commission decisions on the record before the examiner. It also stresses the need for weighing development and safety considerations together in reaching a final policy judgment.

On the basic question whether it is wise to combine in a single agency responsibility for both licensing and promotion and development, opinions are divided. It has been argued that, on balance, the combination is a positive virtue, that the division of these responsibilities between two agencies would sacrifice the balanced judgment that is needed and cause an overemphasis on safety in the licensing function. A vigorous critic of the Joint Committee staff's proposal for the creation of an Atomic Safety and Licensing Board, as well as of the AEC's internal organization and procedures, Professor Kenneth Culp Davis of the University of Chicago Law School, views the proposal, if adopted, as creating in the Board a driver with "a brake but no accelerator and no steering wheel," whereas "the AEC will continue to have all three . . . but . . . will be discouraged from using its brake." He concludes: "If we are to give the public the best protection we know how to provide, we won't have an extra operator with only a brake. We will trust the one driver who can coordinate the use of all the controls. We will trust the Commission as now organized." 39

38 Reply from Prof. Kenneth Culp Davis to the Joint Committee on Atomic Energy, April 19, 1961 [hereinafter cited as Davis Reply], in STAFF of Jornt CoMAr. on Atomic Energy, 87th Cong., 1st Sess., Views and Consments on Inrproving THE AEC Regulatory Process 23,30 ( $\mathrm{Jt}$. Comm. Print 1961) [hereinafter cited as VIEWS AND CoMMENTs]. I understand Professor Davis to believe the appropriate changes at the staff level can mitigate whatever is objectionable in the combination of responsibilities at the Commission level. On the other hand, he sees the members of the independent board, having "only ... negative power," as men who will "gradually exaggerate the safety needs and gradually underestimate the affirmative needs for developing atomic energy." Id. at 29 . He would give great weight to the Commission's expression of fear that the "division of its functions between two agencies ... might well have the two agencies working at cross-purposes . ..." Id. at 30. I believe Professor Davis would not object to an Atomic Safety and Licensing Board that was subject to review by the Commission. 
Both the Joint Committee staff and the Berman-Hydeman studies consider the risk of overemphasis on safety by the creation of an independent board a lesser evil than the objections to the combination of regulatory with promotional and development responsibilities in the Commissioners. Indeed, as the latter study notes, one consequence of the combination of responsibilities may even be a tendency on the part of the Commission to bend over backward by overemphasizing safety. ${ }^{40}$

The Board proposed by the Joint Committee staff and the BermanHydeman studies would, of course, have to take account of the Government's policy to foster the development of atomic power; the safety issue in all licensing cases is how much risk to safety should be run in pursuing that goal. But the Board would neither have had a record of dealings with the applicant in regard to the particular reactor it was proposing nor have backed the applicant's reactor before Congress, put up public research funds for its design, or pointed to it with satisfaction in public addresses and press conferences. The Board's decision could properly be defended before the public in the reactor's neighborhood as the independent judgment of an expert and disinterested tribunal. As is suggested by the anxiety and hostility which have been aroused in a number of communities by the licensing of firms for the burial of atomic wastes off their shores, nuclear power facilities may yet have need for such a defense. ${ }^{41}$

Are Professor Davis and others justified in their fear that a board having only safety as its responsibility would be negative in its outlook and give too much weight to safety considerations in trying to strike a balance? It is important to remember that in the development of an atomic power industry, the achievement of safety is not a fringe consideration of the sort that allows us to tolerate pollution in streams, carcinogens in food and tobacco, and hazards on highways

40 Berman \& Hydeman 231-33; see id. at 301; 2 JCAE Stafr Study 532.

41 For a report on embattled Cape Cod, see Kahn, The Government and the People, The New Yorker, Oct. 15, 1960, p. 104. Thus, an application for a license to dump low-level wastes in containers in the Gulf of Mexico led to intervention by the Sportsman's Clubs of Texas, two counties, the city of Corpus Christi and the Neuces County Navigation District. In addition, the adverse views of the Government of Mexico were transmitted to the Commission through the State Department. The Commission found the applicant entitled to a license for storage but remanded the case for further testimony on the integrity of the containers for sea burial. In the Matter of Industrial Waste Disposal Corp., 2 CCH ATOM. ENERGY L. REP. II 11462.02 (AEC June 22, 1960). The Court of Appeals for the Fifth Circuit found ample evidence to sustain the Commission's exercise of administrative discretion and upheld the AEC. Harris County v. United States, 292 F.2d 370 (5th Cir. 1961). Although the public's fears may be hypochondriacal, the AEC seems to prefer to encourage land burial rather than to arouse them further. See AEC Release No. C-12, Jan. 28, 1960. For a series of informative articles in which a spirited style is combined with a very conservative approach to the problems of radiation safety, see Muldoon, Alice in Nuclear Energy Land (pts. 1-8), Mass L.Q., Dec. 1957, p. 9; March 1958, p. 38; July 1958, p. 55; April 1959, p. 36; Oct. 1959, p. 59; April 1960, p. 37; July 1960, p. 65 ; Dec. 1960, p. 109. 
and airports. The resolution of the reactor safety problem in ways that are economically feasible is vital to the existence of the industry. If safety costs too much, power reactors will not be built; if safety is neglected and a single reactor incident contaminates a single community, atomic power will be at an end for years to come. The Board would know this. The challenge to it to strike the right balance would be imperative; error in either direction could destroy the industry.

The AEC study refers disparagingly to the concern expressed in the other two studies on the score of public confidence as involving "mere considerations of public relations." 42 This surely is misdescription. Whenever public authority is exercised in matters as to which the public cannot be informed, the organization and procedures for its exercise should be such as to command public confidence, since the public has no effective check on performance. The AEC study states, and truly, that "in the long run, it is effective performance which is the firmest foundation for public confidence." 43 But in the interim the people to the leeward of Peach Bottom are entitled to confidence that for them there will be a long run.

What has been said concerning the Commission's dual responsibilities assumes a degree of participation by the Commissioners in the decisional process that is greater than actually occurs, at least in uncontested licensing cases. The actual decisions-except on procedural issues-are made by the AEC staff and the ACRS. Though the staff is "separated" at the time the notice of hearing is filed in a licensing case and may not thereafter communicate with the hearing examiner or the Commissioners, ${ }^{44}$ by that point in time the staff's decision usually will in fact have been reached. If separation were really to be influenceproof, it should begin upon the filing of an application. A stickler for disinterestedness in decisionmaking might still argue that a staff supervised by a Commission that appears committed to support a particular reactor will tend toward bias in favor of that reactor; indeed, the staff may credit the Commission with a greater commitment than it actually possesses.

42 Report on the Regulatory Program, in 2 JCAE STAFF STUdy 415.

43 Ibid.

44 Separation of staff was instituted when the UAW intervened in the Power Reactor Dev. Co. case 1 JCAE STAFF Study 28. It extends to the Division of Licensing and Regulation and the Division of Compliance, to counsel assigned to those divisions, and to "such other portions" of the staff "'as may be required to assist the [former] Division ... in presentation of the staff's position at the hearing." Id. at 18. Paradoxically, the AEC Rules of Practice except cases of "initial licensing" from the separation requirement, the very cases in which the AEC is scrupulously insisting on separation. See 10 C.F.R. \$2.734(b) (1959). The author has learned-unofficially-that this exception was due to inadvertent copying of the same exception from the Administrative Procedure Act, 60 Stat. 239 (1946), 5 U.S.C. $\$ 1004$ (c) (1958), and will soon be corrected in a revision of the Rules. 
If this hazard is real and serious enough, the most thorough means of doing away with it is that proposed in the Berman-Hydeman study: creation of a separate agency in which neither Board nor staff would have promotional responsibilities. But the positions taken by the other studies can be defended on the ground that in both the existing structure and that proposed by the Joint Committee staff there is an independent check on the staff's decision by a disinterested and technically qualified body: under the present system, the ACRS; under the proposed system, the Atomic Safety and Licensing Board and, on occasion, the ACRS as well.

\section{The Decisionmaking Process}

\section{A. Who Makes Reactor Licensing Decisions in Uncontested Cases?}

As this discussion has progressed, it may have grown increasingly evident that the basic problem is the second of the two posed at the outset of this article: how to assure, as nearly as possible, the validity of the safety decisions reached in reactor licensing cases. Therefore, it is necessary to inquire further into the proposition advanced above, namely, that decisions in uncontested licensing cases are actually made by the AEC staff in the Division of Licensing and Regulation. Before doing that, however, some amplification and explanation of the proposition are needed.

In the first place, as has been noted, staff decisions are subject to check by the ACRS before the hearing stage is reached. By the time notice has been given for a hearing, the staff and ACRS have reached substantial agreement. How much disagreement may have occurred en route is not a matter of record; the staff's initial reports to the ACRS are not published; the ACRS "hearings" are not public; and the ACRS reaches its conclusions in executive session. Surely the staff would rarely recommend that a license issue to an applicant over the objection of the ACRS, unless perhaps the disagreement went to some minor condition. Also infrequent would be staff opposition to a license the ACRS viewed favorably. Such opposition, if persisted in, might precipitate a battle of experts that the Commission itself would have to resolve.

In the second place, as was noted in discussing Peach Bottom, a decision by the staff or the ACRS adverse to the applicant is not likely to be challenged, especially at the construction permit stage. As was said in a memorandum reporting a "seminar" composed largely of lawyers experienced in reactor licensing problems:

The applicant realizing the decisive influence of the Licensing Division's opinion and that of the ACRS on a 
hearing examiner, who is not equipped to delve into the highly technical safety matters, prior to the hearing, will have resolved all technical questions with the staff and the ACRS either by convincing the staff and the ACRS of the safety of his project or by making modifications in his design. In the uncontested case the public hearing has not been a forum for resolution of safety questions. ${ }^{45}$

Third, although the decision that the Division of Licensing and Regulation must make in a reactor licensing case takes the form of a recommendation concerning the AEC's position in the hearing to be held on the application, one might suppose that the Division, in arriving at its recommendation, would have to decide the ultimate question that confronts the agency in a reactor licensing case, namely, "whether," to quote the report based on the AEC study," "a specific reactor ought to be allowed to operate in view of the policies laid down in the act as implemented in regulations." But any such supposition is shaken by the very next sentence in the report: "The resolution of that question has no necessary relation to the technical skills of the person or persons constituting the tribunal."

The AEC views the central question as being decided by "the established system of hearing before an examiner, with review by the Commission-and the courts, if necessary . . . .," to quote Commissioner Olson, who underlines the point by adding, "this decisional process is to be distinguished from the technical evaluation process performed by the Hazards Evaluation Branch and the ACRS." 47

This distinction between technical evaluation and policy determination will not wash. How can a body make a "technical evaluation" of safety in a field where absolute safety cannot be attained and only a "reasonable assurance" against "undue risk" is sought, without being free to decide the policy question whether the risks fall within tolerable limits?

The ACRS, in advising the Commission, has been unable to avoid facing the policy question. Professor Theos J. Thompson of M.I.T., Chairman of the ACRS, stated in the June hearings that:

[T] he ACRS as such has considered and does consider and has discussed quite freely what we call the problem of "the gain versus the risk."

There is no question that even a body which is completely involved and solely interested in safety must consider

45 Reply from Atomic Industrial Forum to the Joint Committee on Atomic Energy, April 12, 1961, in VIEws AND Comments 3, 9.

48 Report on the Regulatory Program, in 2 JCAE Staff Study 415. Olson).

17 Hearings on Radiation Safety and Regulation 300 (testimony of Commissioner 
this problem to some extent. There is no way of completely divorcing promotion from safety since, if you want absolute safety, you must not build any reactors whatsoever.

If you make the policy decision to build reactors, then you have incorporated a certain amount of risk and you have incorporated certain gains. This policy decision is up to the AEC.48

The letter from Acting Director of the Division of Licensing and Regulation Robert Lowenstein, advising Philadelphia Electric that the Division did not have sufficient information to warrant issuance of a construction permit for Peach Bottom, ${ }^{49}$ inevitably implied that the Division had reached a policy judgment under the loose standard governing the issuance of provisional permits approved in the Power Reactor Dev. Co. case. ${ }^{50}$

If it is impossible to make a technical evaluation of reactor safety without making a policy decision, is it nonetheless possible to make a policy decision on reactor safety without an understanding of the technical evaluation? It is, of course, possible for any tribunal to decide a question that it does not fully understand; courts have to do this frequently. But the task of the courts which find themselves in that predicament is dispute settlement. Regardless of whether they have a satisfactory grasp of what is at issue, they must proceed to a

48 Id. at 387 (remarks of Prof. T. J. Thompson). Customarily, the ACRS conclusions, when favorable to the applicant, are couched in terms paralleling the AEC's regulations. See, e.g., the ACRS letter in Consumers Power Co., Big Rock Point, Mich., March 14, 1960, in AEC Release No. C-52, March 25, 1960 . For a striking example of an ACRS policy decision, see the ACRS letter of June 30,1960, on the small-size pressurized water reactor, proposed to be built by the AEC at a site near Jamestown, N.Y. The ACRS wrote in part:

The Committee can find no serious technical fault with the reactor, the containment, and the safety features proposed, insofar as the partial information supplied to date has presented the case. The Committee emphasizes, however, that power reactors are relatively new and untried, and that there exists a considerable degree of uncertainty in our knowledge of their longterm safe behavior. Accordingly, the Committee doubts that the new and relatively untried technical features for improved safety proposed by the applicant, since our last report, are a satisfactory substitute for the inherent safety implied by a greater distance from population centers.

The Advisory Committee on Reactor Safeguards strongly urges that, as a matter of policy, the Atomic Energy Commission not build this reactor at this site since the reactor cannot safely demonstrate economic nuclear power or anything else here that it could not do more satisfactorily at a better site.

49 See note 33 supra and accompanying text.

50 In the Matter of Power Reactor Dev. Co., 2 CCH Atom. ENERgy L. REP. II 11201.15, at 17225-47 (AEC May 26, 1959), revd sib. nom. International Union of Elec. Workers v. United States, 280 F.2d 645 (D.C. Cir. 1960), rev'd sub. nom. Power Reactor Dev. Co. v. International Union of Elec. Workers, 367 U.S. 396 (1961). 
decision between the contestants, using as best they can such aids as the rules governing burden of proof.

In the normal reactor licensing case, the hearing examiner is not trying to resolve a dispute. In every case save one, the parties before him have been in agreement that the permit or license should issue. $\mathrm{He}$ is not ordinarily confronted by two conflicting lines of fact testimony and expert opinion between which he must make as good a choice as he can. The fact that there was a potential conflict-c"the interest of the applicant versus the interest of the public," as Commissioner Olson put it ${ }^{51}$-does not cast the examiner in the judge's role, since the conflict has been resolved before the hearing began.

Is the examiner able to say that the shared conclusion of the applicant, the staff, and the ACRS is wrong-or even that it is right? All he knows about the matter is the simplified version presented at the hearing, a version which counsel for the applicant and counsel for the staff have carefully supervised, with a view to the proposed findings that they will submit to the examiner when the hearing is over. Counsel for the staff will frequently try to bring out the significance of the safety issues in the case by his examination or cross-examination of witnesses, and the examiner may ask some questions to advance his comprehension of the case. But this is shadow boxing; unless counsel have botched the job, there will be no basis for the examiner to do other than to accept the decision the staff has reached, unless he can introduce some new rules of the game.

This view of the examiner's limitations has not been accepted by the Commission. In the hearings last spring, Commissioner Olson responded as follows when he was asked by J. T. Ramey, executive director of the Joint Committee staff, whether the examiner was to "go into substance":

Mr. Ramey, the hearing examiner is supposed to make a decision based upon the record on the ultimate question of safety. He is not to contribute evidence from his own mind to that record. He is to take the evidence of the record and to try to conclude whether all evidence available, whatever it be, fact and opinion, is expressed on the record. He then proceeds to try to evaluate the record and to try to evaluate this question of risk as identified on the record, to ascertain whether that record supports a conclusion, a policy and technical judgment on the ultimate question of reasonable assurance of safety. I think that he has a broader function than just to be a notary taking a deposition. ${ }^{52}$

51 Hearings on Radiation Safety and Regulation 374 (remarks of Commissioner Olson).

52 Id. at 313. 
There are, to be sure, opportunities aplenty for the examiner to make rulings that do not go to the merits. He can refuse to order that an applicant be issued an operating license until, at a new hearing, inspectors testify that the reactor has in fact been built as represented in the application..$^{53} \mathrm{He}$ can refuse to order an operating license on the ground that, after the case was noticed for hearing, the applicant submitted a minor technical amendment to his application. ${ }^{54}$ Or, more consequentially, he can limit an operating license to permit operation only up to a specified low power level and postpone a license for a higher level until a new hearing has been held to receive testimony as to the reactor's behavior at the lower level..$^{55}$ The exercise of authority to prescribe ground rules of this nature does not require an understanding of the technical evidence; on the contrary, burdensome rules of the sort noted seem designed as safeguards against a lack of understanding.

It has been urged that a hearing before an examiner has various values: that it provides an orderly public record of the grounds on which the staff approved the reactor, that it puts pressure on the applicant and the staff to do their homework, and that it provides an opportunity for intervention by public or public-spirited bodies. ${ }^{56}$ These considerations-which are most persuasive with respect to the hearing on a construction permit-will be considered later in this article. But it should be stated here that they do not in any way conflict with the proposition that the examiner who lacks an understanding of technical safety issues cannot rationally review the merits of a decision on these issues that has already been reached by the staff.

Is the Commission itself any better able to review the merits of the staff's decision in an uncontested case after the examiner has found for the applicant? How able is the Commission to apply policy considerations without having made its own technical evaluation or having fully understood that of its staff? In one respect, of course, the Commission is in a position superior to the examiner's, for the Commission will usually include two or more technically qualified members and, if technical question marks are sufficiently conspicuous in the record, these members may spot them and push behind the record. Note that, if they were to do so, they would be deviating from the

53 The Commission so ruled, sua sponte, in In the Matter of Westinghouse Elec. Corp., 2 CCH ATOM. ENERGy L. REP. Tl 11223, at 17263-3 (AEC May 6, 1959). See generally 1 JCAE STAFF STUDY 31-33; BERMAN \& HYDEMAN 125-26.

54 See In the Matter of Yankee Atomic Elec. Co., 2 CCH Atom. Energy L. Rep. II 11232, at 17309 (AEC Sept. 26, 1959).

55 See In the Matter of Commonwealth Edison Co., 2 CCH ATOM. ENERgy I. REP. I11229, at 17276 (AEC Sept 26, 1956). This procedure now is embodied in an AEC regulation. See 10 C.F.R. $\$ 50.57$ (Supp. 1961).

56 See 1 JCAE STAFF STUDY 49, quoted with approval by Commissioner L. K. Olson in Hearings on Radiation Safety and Regulation 304-05. 
position the Commissioners appear to have adopted for their informal review of their own hearing examiners' decisions, namely, of viewing the process as analogous to a review of the decision of a lower court, inquiring whether there is sufficient evidence of record to sustain the examiner's findings. ${ }^{57}$ Such use of standards developed for appellate review of judicial or administrative action is perhaps understandable, given the limited time available and the Commission's concern to assure a decision supported by evidence of record, but it is not likely to yield an effective evaluation of the staff's decision. Only rarely will counsel for applicant and staff have failed to provide ample evidence to support the proposed findings they will have submitted to the examiner. ${ }^{58}$

The chance that one of the Commissioner-experts will break through the façade of findings in an uncontested case is small. They are obliged to proceed, usually without argument, on the basis of a necessarily over-simplified record supported by a brief and often enigmatic letter from the ACRS, in such time as they can steal from the many wholly unrelated concerns that press upon time--from test bans to Canadian uranium contracts. Naturally, in such a situation they "usually ask for a briefing of the decision," ${ }^{59}$ which is furnished by a special assistant from the General Counsel's office.

From the time the hearing has been noticed, moreover, the Commission will have cut itself off from any contact with the Hazards

57 Commissioner Graham sees the hearing examiner as analogous to a federal district judge. See Hearings on Development, Growth, and State of Atomic Energy Before the Joint Committee on Atomic Energy, 86th Cong., 2d Sess. 98, 99 (1960); Hearings on Indemnity and Reactor Safety Before the Subcommittee on Research and Development of the Joint Committee on Atomic Energy, 86th Cong., 2d Sess. 234 (1960). The Commission's concern that the record contain sufficient evidence to sustain the examiner's findings and conclusions is manifest in Commissioner Graham's testimony in Hearings on Radiation Safety and Regulations at 309. At that hearing the author questioned the aptness of the Commission's "appellate court review." Id. at 375 . No doubt the Commission would not pursue the judicial analogy as far as to accept evidence as "sufficient" simply because the findings it supported were not clearly erroneous. I should infer that, in their informal appellate review, the Commissioners would seek to gauge whether the evidence in support of the examiner's findings was substantial.

58 In the only uncontested facility licensing case remanded for deficiencies in the record, the lack of evidence on the point at issue was total; the Commission required that matters which had been left to inspection be covered by testimony of record. In the Matter of Westinghouse Elec. Corp., 2 CCH ATOM. ENERGY L. RFP. II 11223, at 17263-3 (AEC May 6, 1959). In a hotly contested waste disposal case, the Commission remanded because, although it said the "record supports the findings of the Hearing Examiner with respect to [the other points in issue] . . . ." the Commission found "insufficient evidence to establish the integrity of the proposed containers after disposal at sea ...." In the Matter of Industrial Waste Disposal Corp., 2 CCH ATOM. ENERGY L. Rep. I 11462, at 17622 (AEC June 22, 1960), aff'd sub nom. Harris County v. United States, 292 F.2d 370 (5th Cir. 1961). On this point, the failure again seems to have been total, since the record did "not disclose any comprehensive testimony concerning the effect of sea pressure." Id. at 17629.

59 Hearings on Radiation Safety and Regulation 312 (testimony of Commissioner Olson). Commissioner Olson prefaced these remarks by stating that each Commissioner takes a good deal of interest in looking over examiners' decisions in uncontested cases from every point of view, procedural and substantive, before they become final. Ibid. 
Evaluation Branch and so will have deprived itself of such illumination as might be provided by discussion with the experts who often will have been worrying over the application for months. Moreover, perhaps for lack of time and occasion, the Commission will not have consulted with other experts in the AEC who are not engaged in regulatory work, though its rules would allow them (but not the examiner) this privilege. ${ }^{60}$ Finally, those Commissioners who are not recent appointees may find it hard to escape recalling the considerations that led them earlier to approve contracting with, providing research funds for, and seeking congressional approval of, the applicant on behalf of this very reactor.

Now and then, procedural questions may be caught, perhaps by the special assistant, which will lead the Commission to depart from the terms of the order as it left the examiner's hands, ${ }^{61}$ but, with all respect for the Commissioners' conscientious conception of their duties, it seems clear that, on substantive matters of safety in uncontested cases, the process of review on the record can scarcely escape from being a rubber-stamp operation in all respects save the time it consumes. In the rare case that is contested, either by an intervenor or by the staff appearing in opposition to the application, the examiner will have to make a decision. If the issue goes to difficult technical matters, there is no reason to presume that the decision will be valid, however faithfully the examiner applies himself to the (probably) immense record. Much time will have been lost to provide a record for review by the Commission. If the Commission perseveres in what it terms its quasijudicial procedure, it will find it difficult to set aside the examiner's order since his findings will probably be supported by evidence of record. But it is hard to suppose that the technically qualified Commissioners would be content to be bound by that rule if they were left uneasy by the situation revealed in the record. They would find that their lawyer brethren have handicapped them by a clumsy procedure-a remand for additional hearings being the indicated route. Perhaps impatience with formalized procedures and the grim specter of mounting costs would lead the Commission to take advantage of the leeway for "initial licensing" allowed by the Administrative Procedure Act and try to get at the heart of the problem by talking to the people who know most about it, unseparating the staff in the process.

\section{B. Is a Review of Uncontested Staff Decisions Needed?}

One who deplored the time spent by the applicant, the AEC staff, and the Commission in carrying through the routine of hearings and

6010 C.F.R. $\$ 2.734($ b) (1959). Compare note 44 supra.

61 See note 53 supra and accompanying text. 
review now followed in uncontested cases (not once but ordinarily several times for each reactor) might well disagree with the Joint Committee staff and the Berman-Hydeman studies that a review of the decision reached by the AEC staff and the ACRS is needed in uncontested cases. Why not treat power and test reactors as research reactors are now treated: if the ACRS concurs, let the staff decide the matter, making public its hazards analysis together with the application, and allow any interested person or body to compel a hearing by challenging the staff's order?

This poses what I have thought to be the key question in the AEC's facility licensing problem: Absent a contest, is there a need for review on the merits of the safety issue decided by the AEC staff and concurred in by the ACRS?

On one aspect of this question, an assured answer is possible: the fact that there is no contest does not mean that there are no substantive questions meriting review. Whatever provision for public notice may be made-and until recently it has been inadequate-there are many impediments to effective intervention. An obvious one is cost. Even if the intervenor is not planning to take his objections to the courts in case he fails before the Commission, very substantial expense is involved in employing counsel and experts needed to analyze carefully the mound of documents thrown up in the prehearing process, to explore questions with the AEC staff and the applicant, and to prepare testimony in support of intervention if agreement is not reached. Few public or private bodies are prepared to spend funds of that order of magnitude, especially when they cannot be sure at the start that the staff and ACRS will not prove entirely correct. Hence we must assume that interventions will be few. Moreover, the ability to enlist scientific consultants at the level of expertise necessary is not open to all intervenors, regardless of their ability to pay. And we have already noted in discussing Peach Bottom the deterrents to contest by the applicant, given the kind of review which the present process provides.

Even if one grants that the problems resolved by the staff and the ACRS in an uncontested case may be just as hard and just as serious as those raised by an intervenor in a contested case, is there any justification for further technical review after the careful study that the matter has already received? This is a question that can be considered both "on principle" and in relation to the respective situations of the two bodies who now make the decisions-the AEC staff and the ACRS.

On principle, there would seem to be a need for a second look at any decision involving the safety of thousands which has been made 
by staff members whose work of necessity has immersed them in the details of the case and brought them in close and frequent contact with the persons whose application is at issue. A detached reviewing body, if technically qualified, is more likely to see the particular facets of a problem in context and perspective; it will not have associated with the applicant's personnel; it will not have had to take tough positions on certain questions - the need for further costly tests, for exampleand so to have developed a "reasonable" attitude on other questions. Moreover, scrutiny by the staff is likely to be more searching if the adequacy of its analysis and its findings must pass muster before another knowledgeable body. At this point, however, is not the need for review met by the ACRS? Doesn't the work of that committee render review by another body redundant?

Clearly the ACRS has been discharging the functions of a reviewing body. But has it been able to do so well enough that no further check is called for; more important perhaps, can it continue to perform its functions as effectively as it has been able to do thus far?

The ACRS is highly regarded. Comments on its work are replete with compliments. On the other hand, the ACRS's workload has been mounting. It has had to rely increasingly on its subcommittees which meet with staff and applicants between sessions of the full committee. The ACRS itself meets at intervals of one or two months and, in a three-day session, "typically reviews 6 to 10 or more projects and completes reports on such projects to the Commission as required by statute." ${ }^{22}$ It is difficult to see how this pace can be stepped up.

An overload would mean less time per case and a spottier selection of questions for detailed consideration. Moreover, though the ACRS is formally a body advisory to the Commission, its close contact with the work of the Hazards Evaluation Branch has led to some of the sort of redundancy that imposes burdens on applicants and could undermine staff morale. ${ }^{63}$

Concern with such considerations, heightened by the fact that the AEC's promotional and developmental efforts may result in still heavier workloads in the future, has led to substantial agreement on the desirability of reducing the ACRS's responsibilities. ${ }^{64}$ Although a dimi-

62 Reply From Atomic Industrial Forum to the Joint Committee on Atomic Energy, April 12, 1961, in VIEWS AND COMMENTs 7. "To perform their difficult task in the limited time available, the ACRS has developed a basically standard form of brief report which varies from case to case only in the degree of enigma built into each letter. The reports usually are not helpful to an understanding of the project because the bases for the committee's conclusions are not set forth." Ibid.

B3 For an extended analysis of the difficult role into which the ACRS is now cast, see BERMAN \& HYDEMAN 107-21.

64 ACRS Chairman Silverman himself suggested that "as time goes on, the staff should gradually assume the responsibility for review of all reactors except new and 
nution in the role of the ACRS as the regular reviewer of staff action would, of course, cut back the protection which that committee now affords, the reduction would not be proportional, for the ACRS would still be available for novel, serious safety questions. Some less obvious problems, however, might slip past the staff, and the staff might also prove less ready to call on the ACRS for advice and support than would be desirable. If the nominal review now provided by the hearing before the examiner and the Commission's look at the record were to continue, dependence on the staff would thus become very great.

Probably the present staff would rise to the responsibility which the shortcomings of the reviewing process would impose upon it, but this response might not persist. Opinion seems general that the Hazards Evaluation Branch staff has been growing stronger, and this trend may continue. But if the demand for atomic power reactors should increase, this staff might find itself raided by industry and forced to begin the building-up process anew just as its workload expanded.

The Joint Committee staff and Messrs. Berman and Hydeman were persuaded that review of the merits of safety issues was needed above the staff level and that this called for a reviewing body that included technically qualified members, ${ }^{65}$ a specification that even the Commission has sometimes been barely able to meet. ${ }^{66}$ The Joint Committee staff did not explore the possibility that the Commission itself might perform that function, partly because of the Commission's

unique types, and the Committee should confine its duties more and more to safety policy matters and to unique nuclear safety problems." 2 JCAE STAFF STUDY 591. The AEC study suggests that, "with the increased maturity of the hazards evaluation staff, the Committee should more and more concern itself with broad principles of safety rather than with a comprehensive review of the specific problems of individual reactors, thus making use of the time and energy of Committee members at a level more commensurate with their high degree of skill." Report on the Regulatory Program, in id. at 406 . The Joint Committee staff study would have references to the ACRS made "on a selective basis." 1 JCAE STAFF STudy 49, 71. The BermanHydeman study would either have the review function of the ACRS merged with the hearing or, after an interim period of two or three years, relieve the ACRS of caseby-case analysis. BerMan \& Hydenran 326.

65 "Two members of the Board should be specially qualified by training and experience in fields of science or engineering relevant to safety. For the third position . . a person knowledgeable in the conduct of administrative proceedings [is needed] : . . "The staff notes that although "no fulltime reviewing body can be expected to embrace all the branches of pure and applied science that may be relevant ... sound scientific training and experience in one field can enable its possessor to appreciate the problems of another field and equip him to evaluate evidence . . ." The reviewer, the staff member, and the scientific witness "speak the same language." " 1 JCAE STAFF STUDY 69,7475. A board composed of "a scientist, an engineer, and a lawyer" is suggested in Berman \& Hydemean 319.

68 Thus, from the resignation of Commissioner J. H. Williams in June 1960 until the appointment in the winter of 1961 of Dr. Glenn T. Seaborg and Dr. Leland Haworth, the only member with scientific training was Commissioner Robert $\mathrm{E}$ Wilson, a chemical engineer who from 1945 to 1958 was board chairman of Standard Oil of Indiana. 
conflicting functions, partly because of the Commission's lack of time. A review process enabling the Commission to reach an independent judgment as to the safety of every proposed power and test reactor at the construction permit stage or of every constructed reactor at the operating license stage (or stages) would, for reasons developed later in this article, mean much more work than its present practice of taking an informal, unofficial look at the cases before the examiner's intermediate orders become final. Moreover, as the Joint Committee staff warned, "contested proceedings to suspend or revoke materials and waste disposal licenses, alone, could dangerously overburden the Commission as a regulatory body." 67 It is simply unrealistic to expect the directorate of a multibillion dollar enterprise with responsibility for many grave governmental policies to take time out of their busy weeks to sit as an examining board in complex and possibly protracted licensing cases, whatever the technical aid that might be afforded them.

The Berman-Hydeman study examined in some detail the possibility of greater participation by the Commissioners in the regulatory process ${ }^{68}$ - for example, by presiding over hearings in major licensing actions and by writing opinions in such cases. However, the authors note that "the Commissioners already are overburdened with responsibilities" and that, as "a practical matter, . . . they may not be able to perform this additional and essential function effectively." ${ }^{69}$ Although they advance various suggestions for reducing the burden that more active participation in regulatory actions would cast upon the Commissioners, they end up by recommending a separate regulatory agency.

The Board concept, as developed in the Joint Committee staff and Berman-Hydeman studies, has two important advantages over the Commission as a reviewing body, apart from the fact that the Board would not have sponsored the reactors for which licenses are sought.

671 JCAE STAFF StUdy 66. A recent summary, AEC's Regulatory Program, in 2 JCAE STAFF STUDY 98-100, lists 525 outstanding operators' licenses for individuals to manipulate reactor controls, 5,798 licenses for domestic possession, use, and transfer of nuclear byproducts, 1,149 licenses for the domestic possession, use, and transfer of nuclear source materials, and 340 licenses for specific uses of nuclear materials. By contrast, there are only twelve power and test reactor construction permits and operating licenses outstanding and 76 permits for research reactors and critical experiment facilities. As the number of these licenses grows, and with it the AEC's compliance and inspection machinery, the number of license suspension and revocation cases is sure to increase, unless the states assume a greater load tunder $\$ 274$ of the act, added by 73 Stat. 688 (1959), 42 U.S.C. \$2021 (Supp. II, 1961), than now seems likely. Only partial protection can be afforded the Commission by its recent action making review of the examiner's intermediate decisions a matter of discretion. See 10 C.F.R. $\$ 2.752$ (Supp. 1961) (effective April 15, 1961). A board could handle this business more readily.

68 BerMan \& Hydearan 286-93.

$60 \mathrm{Id}$. at 289. 
The first of these advantages is that a majority of its members would always be technically qualified. The second advantage is that these members would have time to examine carefully the safety problems coming before them. Of course the Board's review should not be comprehensive; it ought not to inquire into all the matters that the Hazards Evaluation Branch has covered, unless the reactor is so novel that only such coverage will permit a sound judgment to be reached; but it should seek to identify the problems that were troublesome below and probe as deeply into those problems as their difficulty and the hazards involved would warrant. As Dr. Thompson's statement has made plain, ${ }^{70}$ the Board could not escape weighing the gains against the risks but, unlike the hearing examiner and the Commission today, the Board members would know, as nearly as the nature of the questions made possible, what the risks really were.

This does not mean that the Board would always view the risks as larger than the Commission would see them. The contrary might be true. Being free from the need to attest its own objectivity and being adequately informed on the physical problems presented, the Board might well decide on occasion that the staff had been overconservative. Moreover, applicants, able to address their arguments to knowing decisionmakers from whose decision no time-consuming administrative appeal could be taken, might be emboldened now and then to dispute the staff's conclusions and carry their cases to the Board.

\section{What Procedure Should Be Employed in Reactor Licensing?}

In descending order of satisfaction, the AEC, the Joint Committee staff, and the Berman-Hydeman studies all accepted the idea that at least one public hearing should be mandatory in a reactor licensing case, preferably at the construction permit stage. All three contemplated a hearing at which oral testimony would be presented by witnesses, though the Joint Committee staff study stressed the importance of "informal methods of conducting the hearing," including "roundtable' exchanges." "The oral testimony," it added, "would be by way of testing and explaining the views of the experts." 71

Professor Davis has objected strenuously to "trial-type hearings" in uncontested cases. $\mathrm{He}$ and Commissioner $\mathrm{L}$. $\mathrm{K}$. Olson and AEC General Counsel N. D. Naidin have engaged in a spirited exchange of views on the subject of whether in such cases trial-type hearings are prescribed by the hearing requirements in the 1957 amendments to the

70 See text accompanying note 48 supra.

711 JCAE StafF StUdy 72. 
Atomic Energy Act. ${ }^{72}$ That is a question which I shall not consider since, no matter which view is to prevail, the problem of which answer would be the better for the future will remain. Turning to that problem, I believe it will be helpful to consider what criteria should be satisfied by a review procedure for uncontested reactor licensing cases, the usual cases in which the AEC staff, the ACRS, and the applicant are in agreement. Of these, the following desiderata seem to me the most important.

(1) The procedure should inform the general public as fully as is reasonably practicable concerning considerations underlying the staff's recommendations. Criticism of the AEC's failure to provide such information in the Power Reactor Dev. Co. case was one of the factors leading to the 1957 amendments. Recognition of the ineffectiveness of trial-type hearings held in Washington for this purpose led the AEC to institute experimentally last summer a press-conference type of proceeding in the vicinity of each reactor, ${ }^{73}$ a move independently urged by Professor Davis, who also sees it as satisfying, in the absence of a contest, the statutory requirement of a hearing, despite the fact that the presentations are not addressed to any decisionmaker. ${ }^{74}$

In my opinion, the press-conference type of proceeding would be satisfactory for its limited purpose if representatives of the applicant were the only ones to undertake explaining and defending the safety merits of the installation, and the AEC representatives were simply to preside and explain the procedure still to be followed by the AEC in passing upon the license application. ${ }^{75}$ If, as I believe to be the present

72 Professor Davis' views were first presented in his letter to the Committee, see Davis Reply, in VIEws AND Comments 25-27, were repeated in the panel discussion in Hearings on Radiation Safety and Regulation 372-74, 376, were published in an article, Dueprocessitis in the Atomic Energy Commission, 47 A.B.A.J. 782 (1961), and were restated with special reference to the issue of statutory interpretation in the correspondence appearing (with his A.B.A.J. article) in Hearings on Radiation Safety and Regulation app. 6, at 420-27. Underlying these presentations of his views is 1 Davis, Anministratrve Law Treatise $\$ \$ 7.01-10,7.20$ (1958). For the AEC viewpoint, see AEC Memorandum Concerning Mandatory Hearing Requirement under Atomic Energy Act, in Hearings on Radiation Safety and Regulation 382-85. One of the main points at isste was whether the statute requires trial-type hearings.

73 The AEC's intention to initiate this plan at the Vallecitos Reactor in Pleasanton, Cal., was announced, with credit to Professor Davis, by Commissioner Olson, see Hearings on Radiation Safety and Regulation 299. Professor Davis' proposal, as it appeared in Davis Reply, in VIrws and Comments 25, was modified in his $A . B . A . J$. article, by the elimination of the impractical requirement that the public be informed by a "full and detailed" report by the ACRS "giving a full statement of pros and cons with respect to each facet of safety." Davis, Dueprocessitis in the Atomic Energy Commission, 47 A.B.A.J. 782, 784 (1961).

74 See id. at 784 n.12.

${ }^{75}$ Since I believed the AEC was not planning to limit its representatives' role in the manner I have proposed, I questioned at the Joint Committee hearings the wisdom of the AEC plan announced by Commissioner Olson. See Hearings on Radi- 
practice, the AEC representatives address themselves to the safety merits of the reactor, they put the AEC in the position of defending the reactor's safety to the general public before a decision has been reached that it is safe enough to be licensed. Whatever their disclaimers, they add another degree of commitment to the Commission's already compromised objectivity. Obviously this procedure will cause no trouble until the AEC encounters troublemakers in a case in which the proposed reactor is viewed with doubt or hostility by vigilant citizens groups, skeptical scientists, worried PTA spokesmen, and local politicians eager for a new issue. The more canny the $A E C$ representatives are, the more doubt they will sow in the minds of the audience; the more emphatic they are in the reactor's defense, the greater the Commission's commitment will be in the public's mind. If the Commission should later fail to uphold its staff, that will be viewed as a victory for the militant protectors of the local interest and an inspiration to the next community in which a reactor is planned.

(2) The procedure should provide an occasion for which the applicant and staff must prepare in advance a cogent, technically competent summary of their respective positions, and at which they must defend these positions publicly before their peers. The main value of this is in calling forth the best efforts of the participants, in confronting them with the need to check back over their data, their theories, and the reasoning that supports their case. The material on which such presentations are based should be available long enough in advance of the proceeding to alert potential intervenors and enable scientists retained by them to prepare for attending and perhaps taking part in the proceedings. Obviously, the less competent the persons to whom the presentations are made to understand them fully, the less effective will the occasion be as a stimulus to first-rate work by the applicant and AEC staff.

(3) The procedure should provide an opportunity for the decisionmaker, whether an individual or a board, to explore publicly such of the considerations underlying the staff's conclusions as might give rise to doubt, to test by searching questions any assumptions that might seem shaky, and any conclusions that might appear dubious. The participants in the proceeding may assist in this process by their own questioning of the experts but, since, by hypothesis, absent intervention, they are in basic agreement, the questions most likely to illumine shadowy points would probably come from the decisionmaker. In any event,

ation Safety and Regulation 380. Commissioner Olson remarked that he "never took much stock in trying to solve a problem by keeping people in the dark." Id. at 388. Though I share that view, I think the main questions are who should shed the light and when. 
the procedure should disclose publicly not only the considerations controlling the decision on all safety questions that merit review but also something of the quality of the decisionmaking process: Is it such as to command the confidence of those who are able to evaluate the intellectual disciplines and processes involved?

(4) The importance of conducting the inquiries outlined above in public should not compel the sealing off of the decisionmaker from all communications not made in the public proceeding. Detachment of the reviewer from the operations that must later be reviewed would be desirable, as would be standards of conduct to prevent the circumvention of the public proceedings by behind-the-scenes decisionmaking. But, especially in uncontested cases, this should not require straitjacketing precautions of the sort that have been found necessary in regulatory fields in which rival interests do battle for huge stakes.

(5) The procedure should not prescribe public proceedings of the sort indicated above as essential at every stage in a long and complex process such as is involved in power and test reactor licensing. Efforts should be made to avoid repetitive proceedings on questions of minor consequence which will arise from time to time. Provision should be made to screen these questions from others of more serious import; indeed, this screening process itself is an important responsibility.

(6) Finally, the procedure should provide for a means of converting the uncontested case into a contested one if the process of probing the problem or the decision on the application itself should give rise to controversy. The procedure indicated for the contested case should turn not only on the nature of the issues but on the interests and temper of the contestants and the extent to which they may contemplate seeking a review in the courts. Hopefully some contests could be conducted with no more procedural formality than would be necessary in an uncontested case, but, of course, this would have to depend on cooperation, not prescription.

It has been argued earlier in this article that the hearing examiner is not qualified to review the concurring conclusions of the AEC Hazards Evaluation Branch, the ACRS, and the applicant on technical matters. If this proposition is accepted, then no procedure could be designed by which a proceeding over which the examiner alone presided could satisfy the second and third of the criteria listed, the two that are crucial to effective review. From the standpoint both of stimulating first-rate performance by those who conduct the initial studies and of assuring a searching evaluation of their conclusions, the pro- 
ceeding must be held before decisionmakers who include technically qualified people, men who can be viewed as peers of the experts who come before them.

This is a standard the Atomic Safety and Licensing Board could meet. So, ordinarily, could the Commission. Could procedural changes enable the Commission to discharge the review function which the Joint Committee staff study assigned to the Board?

Professor Davis, who chides the Commission for succumbing to "dueprocessitis," a paralyzing malady induced by an overdose of due process in its legal advice, ${ }^{76}$ would have uncontested cases sent "to the five Commissioners, not to a hearing examiner." There would be "no trial, no examiner, and no separation of functions." 77

The Commissioners, if afflicted by individual or collective doubts, would be free to consult with the AEC staff, the members of the ACRS, and the applicant's technical representatives. Professor Davis believes that "dispensing with trial procedure in uncontested cases" and freedom to consult would "to some extent reduce the burden on the five Commissioners." "78 If, in a given case, they reached a conclusion departing from that in which the staff, the ACRS, and the applicant were united, the applicant could convert the case into a contested case and seek a trial-type hearing or an argument, or both, depending on the nature of the disagreement.

Professor Davis has found it unnecessary to prescribe any procedure for the five Commissioners to follow, once the case has been sent to them, and therefore, in attempting to gauge the impact of his proposal on their burden, I must indulge in conjecture. To begin with, I note the difference between the direct routing he proposes and the way the uncontested case reaches the Commission today, preceded by the full panoply of a formal "trial-type" hearing, the examiner's findings, intermediate decision, and order which will become final after forty-five days, assuming, ex hypothesi, no exceptions to it have been filed within twenty days. However burdensome to the staff and applicant, this facilitates the informal, appellate-court type of review which I believe the Commissioners now give.

With this apparatus eliminated, I suppose the staff would at least draft a proposed order prescribing the terms of the construction permit

76 For a more complete etiology, see Davis, Dueprocessitis in the Atomic Energy Commission, 47 A.B.A.J. 782 (1961).

77 Davis Reply, in VIEws AND Comments 24-27; see Davis, Dueprocessitis in the Atomic Energy Commission, 47 A.B.A.J. 782, 784 (1961).

78 Davis Reply, in VIEws AND Comments 28. The range of consultation contemplated by Professor Davis in this statement, $i d$. at 24 , extends beyond consultation with the AEC technical staff, the only consultation he mentioned in Dueprocessitis in the Atomic Energy Conmission, 47 A.B.A.J. 782 (1961). 
(or operating license) and probably would show it to the applicant so that any objections could be ironed out in advance. The documentation provided the Commissioners by the staff would doubtless include that presented to the press-conference-type hearing, though, of course, the massive material filed by the applicant in the proceeding would also be available. Maybe this would be as good for the purpose of a quick formal initial decision by the Commission as the record it now receives is for a quick informal Commission review. However, recalling that at the press conference the good folk of the vicinage had been assured that the decision would be made by the Commissioners themselves, I should think they would be rather more hesitant to make a quick formal initial decision than they would be to make a quick informal review decision. If so, no doubt they would ask for guidance, calling in technical people, if need be, from all the sources Professor Davis has suggested should be available to them.

Whatever one may think of this mode of decisionmaking because of its behind-the-scenes character, it seems likely that the Commissioners who pursued these consultations could learn more about the safety issues in the case than they are likely to in their present review procedure. But that this educative process would not "reduce the burden on the five Commissioners" seems to me self-evident.

A scheme of decisionmaking which would require the Commission to make the initial decision on the issue of safety in all uncontested cases would confront the Commissioners with a dilemma. Either they could keep their regulatory workload down to its present dimensions by devoting no more time to their decisionmaking than they do at present, or, instead, they could devote whatever time and attention they needed to achieve a real understanding of the questions faced by the ACRS and the staff and arrive, as a body, at answers based on that understanding.

As I see it, if the Commission devoted to its initial decisionmaking only the time it now gives to review, it could exercise a kind of continuing supervisory authority over the work of the Division of Licensing and Regulation, once in a while moving into a case that struck the Commissioners as worrisome. This procedure would, in my opinion, be justifiable as a substitute for a careful case-by-case review of power and test reactor license applications only on the assumption that no review was really needed in the absence of a contest, a view I do not accept.

The latter horn of the dilemma presents different and perhaps more serious difficulties. The increased burden on the Commissioners could be carried only at the expense of their other important duties. I 
should expect the task of reviewing the recommendations of the hazards evaluation staff would gradually be taken over by a technical staff at the Commission level, and the Commissioners would find themselves providing a façade behind which their technical and legal advisers would reach the decisions the Commissioners would sign. This has happened before in Washington.

In either event, the review would not provide the benefits of a public proceeding. To provide those, a body such as the proposed Atomic Safety and Licensing Board seems necessary. But should the Board hold a hearing of the sort now held before the examiner? Professor Davis sees need for a trial-type hearing only on contested issues of fact and sometimes on "issues which are only somewhat factual"; on contested "non-factual issues of policy or discretion" he would use "argument procedure that resembles the procedure before an appellate court," unless the latter issues are "mixed up with issues of fact" that are contested. ${ }^{79}$ But here, at the start at least, there are no contested issues whatever, and so, happily, I am relieved from any temptation to play Procrustes in order to fit the proceeding which I think is indicated into either of the twin beds that Professor Davis has made for classifying hearings that decide contests.

The licensing review proceeding constitutes an examination into a complex set of facts-including theories and expert opinions-in order to appraise the conclusions reached by the $\mathrm{AEC}$ staff which has conducted the basic investigation and by the AEC's adviser, the ACRS. This review is not designed to resolve disputes but to check judgments-judgments on interrelated scientific, technological, and policy questions. Yet in the process of checking these judgments, the examining board may, through its process of study and questioning, find itself growing doubtful of the factual foundations of the conclusions reached by the staff at certain points, and it may call for more evidence, possibly for new research and experimentation. Its role should not be conceived as that of an umpire in an adversary process. Rather, its role should be much more affirmative, and its procedure more flexible and less formal.

Perhaps the best analogue to the Atomic Safety and Licensing Board that I have envisaged is none other than the ACRS as it now operates. The main differences between the proposed Board's review as I see it and the ACRS review as it is now conducted are these: First, the Board's review proceedings would be public. Second, the Board's review would tend to be somewhat more comprehensive and less of a spot check, though certainly the Board should not reexamine

79 See Davis Reply, in VIEws and Comments 27, 31. 
every point covered in the staff's investigation. Third, the Board would ordinarily conduct more extended inquisitions into the findings and thinking of the applicant and AEC staff, though, if due account is taken of the work of ACRS subcommittees, this might not be the case. Fourth, the Board would clearly be charged with the resolution of such policy issues as might be presented by the application, whereas the ACRS deals with them only when they are inescapably bound up in its assessment of safety. And finally, the Board would provide a disappointed applicant with an adequate opportunity to meet the Board's objections by evidence or argument and even to create a formal record so that the applicant might seek judicial review of the Board's final action, however minimal its chance of success might be.

If an Atomic Safety and Licensing Board were to be created, one of its most challenging functions would be to experiment with different modes of proceedings. If the documents should disclose a complex case, the Board would doubtless resort to a prehearing conference. There, informally but searchingly, it could explore with the applicant and staff and any intervenors the problems that seemed troublesome and decide what path its proceedings should follow after an initial public hearing to subject the applicant's case for the construction permit to the scrutiny of the Board and of technically qualified representatives of the interested public. Sometimes, no doubt, the Board might decide to postpone that hearing and refer the matter to the ACRS if its opinion had not already been obtained. Often, one may hope, especially after the construction permit stage, the problems raised would lend themselves to the "informal hearing procedure" which, under AEC regulations, "may partake of the nature of a conference, or may assume some of the aspects of a formal hearing . . . ." 80 The regulations now require hearings to be formal in "cases of adjudication"construed to include hearings in power and test reactor licensing cases-"unless the parties otherwise agree." 81 Agreement on informality could, of course, be predicted more assuredly with a technically qualified Board presiding than with a hearing examiner. Indeed, this characteristic of the Board opens the door to flexibility in the conduct of hearings.

If the Board's probing should bring to the surface a serious disagreement either between applicant and staff or between them both and itself, then the Board might find it desirable to conduct a more formal hearing on the issues involved. ${ }^{82}$ Insofar as the issues involved

80 Rules of Practice, 10 C.F.R. $\$ 2.720$ (1959).

8110 C.F.R. $\$ 2.708$ (1959).

82 In some areas, notably liquor licensing, administrative or judicial hearings are commonly used to review license denials made initially without hearings. See Byse, 
factual questions, resort might be had to formal examination and crossexamination. If, despite the forensic efforts of applicant's counsel and experts, the Board should still decide against the applicant, a formal record would be available for an appeal to the courts. I see no reason why a pattern similar to this might not be followed where the staff and the applicant are in overt disagreement from the start or where an intervenor has taken issue with them both. Neither situation should change the basic nature of the proceeding. Its primary purpose still would be to review the judgment on safety, not to settle the dispute.

The fourth and fifth of the criteria listed above are designed to enhance the efficiency of the procedure by relieving the Board, the AEC staff, and the applicant, from the necessity of acting at all times through the medium of public sessions, with virtually all other communication cut off between the decisionmaker and the other participants in the process. I have already noted the problems that have to be taken into account in authorizing such relaxations. However, the existence of an Atomic Safety and Licensing Board would facilitate the solution of the first of these: it could readily relieve the AEC staff of the sometimes difficult task of deciding when its own conclusions do not require review.

\section{Should a Technically Qualified Board Be Disqualified?}

The expertise of the proposed Board appears to Commissioner Olson not as an advantage but as a danger. He is troubled by "the concept of having the Board, the decisional group, actually contributing to the evidence." $83 \mathrm{He}$ explains that his "concept has always been that the judge or adjudicator, marshaled and evaluated the evidence rather than supplying testimony from his own omniscience. This is the thing that bothers me," he continues, "the concept of having the technical experts at the decisional point. If there is evidence, fact or opinion, skimpy or solid, why can't we get it on the record?" And he adds that "our experience has shown that it has gone on record easily." 84

Here Commissioner Olson reveals a viewpoint that may throw some light on his satisfaction with the AEC's present procedures. First, he seems to regard the decisionmaker in a reactor licensing case as essentially a judge presiding impartially over a controversy brought before his bench, not as an official on whom the nation is relying to

Opportunity to Be Heard in License Issuance, 101 U. PA. L. REv. 57, 72-87 (1952). Discussions with the author, my colleague, Professor Clark Byse, have aided me in considering the AEC's problems of hearing and review.

83 Hearings on Radiation Safety and Regulation 382.

84 Ibid. 
achieve as accurate an understanding of the risks created by a given reactor as the state of the art and of scientific knowledge will permit and to weigh those risks against the gains which that reactor, if licensed, could bring to the development of atomic power.

Second, Commissioner Olson apparently sees the problem in terms of evidentiary fact rather than of trained judgment. If all the facts are marshaled in evidence, including the expert opinions of scientific witnesses, then he appears to believe that an intelligent and honest judge can be relied on to reach as valid an answer to a question of risk as the intelligent and honest scientist-decisionmaker. The problem is simply to make sure that everything relevant gets into the record. But the crux of the problem is not what is in the record but the "judge's" ability to evaluate the record-the facts, the scientific theories, the projections of experiments, the opinions of scientific witnesses. This ability a scientist who has won the respect of his peers will have acquired over many years during a career of study, training, and experience. Inevitably, in exercising it, he will draw on the readings, observations, calculations, experiments, and experiences that have gone into that career, using such insight, "feel," and powers of logical analysis as he possesses. These cannot be put into a record, not should they be looked upon as evidence bootlegged into the case. As Mr. Justice Holmes said of another body many years ago, "the board was created for the purpose of using its judgment and its knowledge." 85

In order to settle all the diverse disputes that arise among its citizenry, a nation has to rely on the ability of its judiciary to move from one type of controversy to another, handicapped sometimes by lack of knowledge in evaluating unfamiliar data, but skilled always in giving the parties to these controversies a fair chance to make their positions understood and persuasive. But the United States has not created the complex regulatory mechanisms of the Atomic Energy Commission just to give parties who want to build and run reactors a means of settling fairly their disputes with the Government or third

85 See Chicago, B. \& Q. Ry. v. Babcock, 204 U.S. 585, 598 (1907). "Evidently also the members [of the Nebraska State Board of Equalization and Assessment] or some of them used their own judgment and their own knowledge . . . which they had a right to use, if honest, however inarticulate the premises . . . [Their judgments] express an intuition of experience which outruns analysis and sums up many unnamed and tangled impressions; impressions which may lie beneath consciousness without losing their worth." Id. at 596, 598. In some fields even a lay board may, by prolonged experience, gain an expertness which they are free to draw upon even though it conflicts with expert opinion of record. See McCarthy v. Industrial Comm'n, 194 Wis. 198, 203-04, 215 N.W. 824, 825-26 (1927) : "It is scarcely too much to say that [the Industrial Commission members] . . are experts upon the subject [of traumatic hernia] ... If the testimony of these [expert] witnesses was contrary to [the Commissioners'] . . . own expert knowledge . . they were at liberty to disregard it" 
parties. In discharging its regulatory responsibility, the Commission's prime duty is to give the nation reasonable assurance that the reactors it licenses do not create undue risks to the communities that are exposed to them. The basic question is how that assurance can best be given.

\section{The AEC's Rulemaking Function}

The AEC is equipped with rulemaking authority, unhampered by any special statutory procedures. It has already issued a considerable volume of regulations, both procedural and substantive. Its output of these has stepped up materially in recent months ${ }^{86}$ after its slowness in rulemaking had become the target of industry criticism. ${ }^{87}$

The AEC's rulemaking authority has been a significant factor in the evaluation of the proposals developed in the three studies. Both the $\mathrm{AEC}^{88}$ and the Berman-Hydeman studies ${ }^{89}$ criticized the Joint Committee staff position because it would leave final rulemaking power in the Commission while giving final power to pass on license applications to the Atomic Safety and Licensing Board it proposed. The AEC study would retain both powers in the Commission while creating a Director of Regulation reporting directly to the Commission as a means of expediting the Commission's regulatory work. ${ }^{90}$ The Berman-Hydeman study would shift both powers to its three-man Atomic Energy Board, although permitting the Atomic Energy Administrator to sit and vote with the Board when it was passing upon proposed rules. ${ }^{91}$

The objections to the Joint Committee staff proposal seem to me to overlook the very significant differences between evaluating the safety merits of an individual reactor-the licensing task to be left to the Board-and adopting regulations of general applicability to broad categories of facilities-the rulemaking task to be left to the Commission. In the former, the need for expert understanding of complex hardware and physical processes is paramount; in the latter, the wise

86 Commissioner Olson, on June 15, 1961, testified: "Since January 1, 1961, we have issued 10 effective regulations and amendments of regulations and 8 notices of proposed regulations covering both procedural and substantive rules." Hearings on Radiation Safety and Regulation 299.

87 See ibid.

88 Report on the Regulatory Program, in 2 JCAE Staff Study 419.

89 BeRMAN \& HYDEMAN 317-18.

80 The position of Director of Regulation has already been created and Harold L. Price, for many years Director of the Division of Licensing and Regulation, has been named Director of Regulation, Dr. C. K. Beck, Deputy Director, and Robert Lowenstein, Director of the Division. AEC Release No. D-247, Sept. 25, 1961.

91 Berman \& Hydeman 328. Surely an administrator would prefer to have no vote than to be thus associated in board actions which he might oppose. 
balancing of the Government's dual objectives in a general rule. However, if the Commission should allow zeal, say, for reducing reactor capital costs to lead it to propose standards of reactor construction that the Board deemed unwise, the Board could make its voice heard both before a rule was issued and afterward, if its views were not heeded. Indeed, the issue might reach the Joint Committee on Atomic Energy and lead ultimately to legislation. ${ }^{22}$

It is borrowing trouble to assume conflicts of this sort. A more realistic forecast would see the Board as a fruitful source of suggestions for rules and an active contributor of ideas for their formulation. The fact that rules grow naturally out of a process of case-by-case decision does not mean that the same people who have decided the cases must be the ones to formulate the rules. Indeed, our governmental tradition is to the contrary.

I suspect, moreover, that current writings may tend to exaggerate the significance of the AEC's rulemaking process. The Commission has just been through a seven-year period of legislative development in which it has gradually evolved a structure of basic rules which is now nearly complete. Sometime in the future another important wave of rulemaking may occur when the stabilization of the art over wide areas will make it possible for standards of good practice in reactor construction and operation to be cast into legislative form. When this can be done, the burden of gradually evolving standards by case-by-case decision will be lightened, although, if the technology continues to break new ground, the latter process will certainly not come to an end.

In any event, extensive formulation of reactor safety standards in regulations is sufficiently far away ${ }^{93}$ that its bearing on what is the best administrative structure for, say, the next ten years, should not be overemphasized.

\section{The AEC's Internal and External Relationships}

A factor stressed in both the AEC and the Joint Committee staff studies in favor of keeping the licensing and other phases of the regulatory function within the same organization that handles promotion and development is ease of communication between the technical staff in the Division of Licensing and Regulation and the staffs in the

92 The Board would report to the Joint Committee. 1 JCAE STAFF Study 70.

93 Relevant to the difficulty of generalizing reactor design experience into standards or "guides" is the testimony by Dr. C. K. Beck, Assistant Director of the Division of Licensing and Regulation, in Hearings on Radiation Safety and Regulation 31: "No two reactors, even of the same generic type are sufficiently alike that extrapolations on many of the parameters for one reactor can readily be made to another. . .." Even small differences in design details "can have disproportionately large effects on ... the performance . . . of a reactor." 
Division of Reactor Development and the National Laboratories. This was thought important not only to promote exchange of information relevant to both processes but to preserve the morale of the regulatory staff which might otherwise regard itself as isolated from the main stream of technological progress. The sharing of a common building and common services which the Berman-Hydeman study proposed as a means of mitigating the possible hazards of separate agencies seems neither an adequate nor a durable safeguard.

There promises to be a continuing, perhaps a growing, need for safety research directed to the design and operation of reactors. ${ }^{94}$ If research staffs are not to be duplicated, most of the governmental work will continue as heretofore to be done by the AEC's Division of Reactor Development and the National Laboratories. Under the BermanHydeman proposals, the separate Atomic Energy Board might experience difficulty in getting its safety research ideas implemented. In the present AEC, the only independent voice for safety research is the ACRS, which is preoccupied with reviewing an unending succession of individual facilities. The creation of an Atomic Safety and Licensing Board within the AEC would add another independent voice for safety research. The Board could contribute ideas of its own and could strongly reinforce the views of the Division of Licensing and Regulation and the ACRS.

The Joint Committee staff proposal has been criticized by the AEC and several commentators on the ground that it would place the regulatory staff in an unsatisfactory role-that the staff would have to try to serve both the Board and the Commission in whose chain of command they would fall. ${ }^{95}$ But the staff would not have to serve the Board any more than an attorney general's office has to serve the courts before which its attorneys appear. To be sure, the relationships between the Board and the staff would be less formal and the opportunities for useful interchange and cooperation outside the handling of licensing cases would be much greater. However, a degree of reciprocated independence on the part of staff and Board would be desirable. Indeed, the fact that the Board, with the ultimate power of decision, is not in a position to supervise and promote members of the staff which carries out the initial investigation and evaluation should make for sounder judgments by both bodies. Instead of a defect in the Joint Committee staff's proposal, I view the separation of staff and Board as a positive virtue.

94 See, as to directions for needed research, Reply From Advisory Committee on Reactor Safeguards, U.S. Atomic Energy Commission, to Joint Committee on Atomic Energy, April 8, 1961, in VIEwS AND CoMments 1-3.

95 See, e.g., Hearings on Radiation Safety and Regulation 300 (testimony of Commissioner Ölson). 
The substitution of the Atomic Safety and Licensing Board proposed by the Joint Committee staff for the present review by the examiner and, on petition, by the Commission, should make for more efficient handling of regulatory work. As is contended by the Joint Committee staff, ${ }^{06}$ the greater accessibility, flexibility, and informality of the Board in power and test reactor licensing should render the Board proceedings more expeditious than those now prevailing, even assuming that the latter are modified to eliminate superfluous hearings, especially in simplifying the consideration of license amendments-the "changes" problem which has been the source of much difficulty. ${ }^{97}$ As has been noted above, it is, of course, possible that the availability of a technically qualified Board would lead applicants to contest more staff positions, but surely applicants cannot complain of licensing delays caused by their own efforts to secure the reconsideration of decisions reached at the staff level.

The Berman-Hydeman study proposes that the AEC-or, if the Atomic Energy Board it advocates is created, the Board-should serve as:

a focal point for coordinating the detailed responsibilities of all Federal agencies [for radiation protection], for evaluating and providing general guidance on the emphasis and direction of research in the field, for integrating state and federal programs of radiation protection, for serving as the initial and principal point of contact for the states particularly with respect to State legislation and rules, for developing and promulgating basic guides, and for formulating broad national policy on radiation protection. ${ }^{.8}$

Once these roles were allocated to the AEC or the Board, the authors would have the recently created interdepartmental Federal Radiation Council ${ }^{99}$ done away with.

I would agree with the authors that the Board they propose would be the logical repository of the responsibilities they list and probably one that could be charged with those duties more readily than the AEC itself. But, unfortunately, the crisscrossing lines of jurisdiction, aspiration, and operation, both among the federal agencies involved and

961 JCAE StafF Study 74-75.

97 This problem, which merits more detailed consideration than is possible here, is illustrated in Vallecitos Boiling Water Reactor case, In the Matter of General Elec. Co., 2 CCH Atom. ENERGy L. REP. \l1236 (AEC Nov. 2, 1960), discussed in 1 JCAE STAFF STUdy 35-37.

98 BERMAN \& HYDEMAN 297-98.

99 See generally Staff of JoInt Comm. on Atomic Energy, 86Th CoNg., 2ND Sess., Hearings on "Radiation Protection Criteria and Standdards : Their Basis AND. USE"-Summary ANalysis 32-35 (Jt. Comm. Print 1961). 
between them and the states, will probably not soon be brought into a nicely coordinated pattern of the sort Messrs. Berman and Hydeman project. Both federal and state agencies must first have achieved more experience in the administration of atomic energy programs and in the regulation of atomic activities. Then they will know better what they should be prepared to concede and what to fight for. The problem does not seem to me to have much bearing on the choices the three studies currently pose.

\section{A CoMpromise BILl}

In the first session of the eighty-seventh Congress no choice was made among the alternatives presented by the three studies. However, identical bills relating to the subject were introduced by Chairman Holifield of the Joint Committee on Atomic Energy in the House ${ }^{100}$ and Vice-Chairman Pastore in the Senate. ${ }^{101}$ No new hearings were held on these bills, and they were not reported out. It seems likely that this measure will be considered further at the present session of Congress, although, of course, it may be supplanted by another proposal. Accordingly, I shall deal with it briefly (terming the bills "the Holifield-Pastore bill").

The bill would add a new section 191 to the Atomic Energy Act of 1954, authorizing the creation, at the option of the AEC, of a three-man Atomic Safety and Licensing Board, two members to be "technically qualified" and the third, "qualified in the conduct of administrative proceedings." 102 If the AEC chose to exercise its option, it could create either an ad hoc or a permanent Board, drawing personnel from its own staff, from other federal agencies, or from among persons in private life. The Board would "conduct such hearings and make such intermediate or final decisions as may be required" for actions in licensing or authorization cases. ${ }^{103}$

The bill would also amend section 189 (a) of the act to make a public hearing for power and test reactors mandatory only with respect to construction permit applications; at the operating license stage a hearing, unless demanded by an intervenor, would be discretionary with the Commission. Hearings on amendments to construction permits or operating licenses might be dispensed with on thirty days' published notice, and, if the Commission determines "that the amendment

100 H.R. 8708, 87th Cong., 1st Sess. (1961).

101 S. 2419, 87th Cong., 1st Sess. (1961).

102 S. 2419, H.R. 8708, 87th Cong., 1st Sess. (1961).

103 Ibid. An "authorization" is the end product of "parallel proceedings" antecedent to the construction of a reactor to furnish power to a state, local, or cooperative electric system, title to the reactor being retained by the AEC. The Commission might delegate still other regulatory functions to the Board. 
involves no significant hazards consideration," it may dispense with the notice. ${ }^{104}$ Although, under the bill's amendment of section $182(\mathrm{~b})$, ACRS review would still be required for power and test reactors at both stages and might also be obtained by the Commission for other facilities, nevertheless, the amended section would require ACRS review of amendments to permits and licenses only upon specific reference by the Commission. ${ }^{105}$

The provisions with respect to hearings and ACRS review reflect generally accepted views. Where the bill would leave a hearing discretionary, presumably the Commission or the Board could proceed by press conference as Professor Davis has advocated, so long as everyone concerned remained in agreement. Moreover, even where a hearing is provided, less formal proceedings than have been the AEC's standard operating practice may be possible. The "Bill Analysis" which accompanied the measure included a paragraph of special interest in this connection:

It would be expected that the Board, at least in initial licensing cases, and in the absence of intervention, would be free to consult with the technical staff to the extent permitted by the Administrative Procedure Act (5 U.S.C. 1004(c)). Similarly, it is hoped that the Board would follow procedures appropriate to the resolution of complicated technical and scientific questions, keeping in mind the necessity for preserving a suitable record for review. ${ }^{108}$

Most debatable are the bill's provisions giving the Commission the option to substitute a board for the hearing examiner. This plan calls to mind a brief colloquy between Mr. Ramey and Commissioner Olson during the June hearing. ${ }^{107}$ However, the idea that a board

104 S. 2419, H.R. 8708, 87th Cong., 1st Sess. \$2 (1961).

105 S. 2419, H.R. 8708, 87th Cong., 1st Sess. \$3 (1961).

106 This "Bill Analysis" was prepared by the Joint Committee staff and circulated informally among interested persons at the close of the congressional session last year. It has not been published formally.

${ }_{107}$ When Mr. Ramey took note of a report that the examiner had been given a "technical adviser," Commissioner Olson acknowledged that this was true, crediting discussions with Mr. Ramey for the idea and adding: "[The Commission] . . . decided that it might be well to try this out, to give him a law clerk, so to speak, with a technical background who could go through the testimony, the narrative testimony, the application, so that the examiner could discuss it with some technical competence. We are trying this out. It has not been startlingly successful, but we are continuing with it." Hearings on Radiation Safety and Regulation 313-14. Mr. Ramey, "somewhat humorously," as he remarked later in the hearing, then asked: "What if you gave him one more technical assistant and called it a Board?"

Mr. OLSON. I think that has a lot of merit. I think that has a lot of merit provided you would not clothe it with complete independence of authority and make it separate but within the Commission. I think that has a lot of merit.

Mr. RAMAEY. So you have a little Board there. Then the other thing that has happened since the Committee's staff report was that the Commission established this rule of a certiorari procedure so that the decision of your 
might be created ad hoc was suggested earlier on the same occasion by James M. Landis, then a Special Assistant to the President for Administrative Agencies. ${ }^{108} \mathrm{Mr}$. Landis had already recommended that, if a board were created, it be appointed by the Commission rather than by the President, as the Joint Committee staff had suggested, and that its decisions be subject to discretionary review by the Commission, ${ }^{109}$ a point also stressed by Commissioner Olson. ${ }^{110}$

Obviously whether one would view the adoption of the plan embodied in the Holifield-Pastore bill as a major step forward in meeting the AEC's facilities licensing problem would depend on whether one thought the more serious defect to be corrected was the present lack of an adequate review by a technically qualified body or whether, instead, one were chiefly concerned by the dual functions of the Commissioners. The Board, if employed by the Commission, should materially strengthen the technical review process, at least if the Commission were to appoint scientists and engineers of high standing to it. That the Commission could enlist such persons on an $a d$ hoc basis for a difficult case seems likely; probably it could not do so for a permanent Board, given the extent to which the Board would be subordinated to the Commission.

The very fact of subordination would tend to leave the Commission wearing its two hats, to the detriment of public confidence in the disinterestedness of its decisions. However, if it were to make the Board's decision final in a given case, this might provide insulation enough from its policies, especially if the men the Commission chose for the Board enjoyed high reputations in their respective fields.

If the Board took full advantage of any relaxation in procedural formalities permitted by the Commission, the use of the Board might well prove more expeditious than the use of the hearing examiner. However, if the Commission used hearing examiners who were prone to "dueprocessitis," as Professor Davis puts it, to serve as presiding officers and if the Commission were liberal in accepting petitions for review of the Board's decisions, the main procedural effect of the Board's creation would be to substitute a new layer for the existing one in the decisional process.

Hearing Examiner or . . your Hearing Examiner and two technical assistants, is final so far as the applicant is concerned.

Id. at 314 . Mr. Olson. Subject to our right to review on our own motion. Landis).

108 Hearings on Radiation Safety and Regulation 246 (testimony of James M.

$109 \mathrm{Mr}$. Landis was the source of the suggestions reported in 1 JCAE STAFF STUDY 69, $70 \mathrm{nn} .2,3$.

110 See note 107 supra. 
From the foregoing it seems evident that an appraisal of the Holifield-Pastore bill as a compromise between the views of the Joint Committee staff and the Commission ${ }^{111}$ must await a reading of the Commission's reaction to the plan. The Commission could render such a plan a step backward or it could make the plan an instrument of progress. In any event, it seems clear that the Holifield-Pastore bill, if considered at this session, would provide an excellent vehicle for another careful look at decisionmaking by the AEC in nuclear facilities licensing.

111 The recently published Hearings on Radiation Safety and Regulation app. 7 , at 427 , contain a letter dated July 24,1961 , from AEC Chairman Seaborg to Joint Committee Chairman Holifield, proposing amendments to $\S \S 189$ (a) and 182 (b) to limit the mandatory public hearing and ACRS reference requirements to the construction permit stage. A like letter, dated July 27, 1961, presented a draft subsection for $\$ 189$ to authorize the Commission to "designate two or more persons to serve with a duly appointed hearing examiner as a board to conduct hearings and render a decision in accordance with the Administrative Procedure Act . . . " Chairman Seaborg explained that the board would be "established on an ad hoc basis for individual cases" with authority "commensurate with that of a hearing examiner." In his reply, dated Aug. 7, 1961, Chairman Holifield indicated that, although he saw no objection to such use of a hearing examiner, the AEC might "wish to try outside people also." Accordingly the authorization was recast in the broader terms indicated in the text above as a new $\$ 191$. The letter also transmitted broadening language for the amendments to $\S 189$ (a) and $182(\mathrm{~b})$. 